\title{
Performance of irrigation projects and their impacts on poverty reduction and its empowerment in arid environment
}

\author{
A. A. Irajpoor; *M. Latif \\ Center of Excellence in Water Resources Engineering, University of Engineering and Technology, \\ Lahore, Pakistan \\ Received 29 June 2010; ～revised 15 October 2010; accepted 7 February 2011; available online 1 June 2011
}

\begin{abstract}
Biophysical and socioeconomic conditions of pre and post dam construction were assessed in one of the arid regions of Iran commanded by Minab dam. The methodology used in this study was drawn from the international organizations especially the World Commission on Dams and the United Nations for selection of the indicators for sustainable development relating to water resources projects. Commissioning of the dam in 1986 led to progressive expansion of the irrigated agriculture, which was almost doubled in year 2006. Results of the study revealed that there is significant positive impact of the irrigation infrastructures of the dam; for example literacy rate has increased from $41 \%$ (pre project) to $74 \%$ in 2006. Similarly, significant improvements were observed in health care, sanitation, education and other scopes. Nevertheless, for some of the targets only 50-60 \% progress were made, whereas no significant achievements had been made in the others. Therefore, development did not match with the planned goals of the project. Deficiency in achieving the primary objectives, especially after many years of project completion, may be attributed to the management and implementation of the project. For effective project performance, a new institutional framework and guide lines are proposed in this article.
\end{abstract}

Keywords: Achievements; Institutional framework; Management; Sustainable development indicators

\section{INTRODUCTION}

Water is vital for life since human beings can not survive more than a few days without it. In many countries, water resources have become scarce due to the increasing demand on limited water resources. The importance of water resources management in water stressed areas, especially in arid countries is sine qua non (Dikinya and Areola, 2010; Brahim et al., 2011). Historically in arid regions, the dwellings developed mostly along the rivers or some other water source as happened in many ancient civilizations, e.g. Iran (side of Karoun River), Mesopotamia in Iraq (area between Tigris River and Euphrates River), Egypt (side of Nile River) and the Indus valley civilization in the subcontinent which covered a large part of Pakistan and northwestern India, situated around the Indus and the Ghaggar-Hakra rivers, respectively (Marco and Dorian, 2006).

According to current estimates, by the year 2030, world population will rise from the present 6.2 billion to 8.7 billion. Almost 800 million people in developing

\section{*Corresponding Author Email: drmlatif@yahoo.com} Tel./ Fax: +9242 99250256 countries today face chronic malnutrition and 199 million children under the age of five suffer from acute or chronic food deficiencies. At present, as many as 70 nations fall into the category of low-income food-deficit countries (FAO, 2011). Worldwide high benefits are being derived by those countries who have established sustainable irrigation systems in the arid regions. Currently $47.2 \%$ of the world and $45.8 \%$ of Asia and $90 \%$ of Iran fall in arid climate where no crops can be grown without irrigation. Irrigation is an essential part of the package of technologies, institutions and policies that underpins increased agricultural output in Asia. Past experience shows that this package, although broadly beneficial to societies, has not yet fully succeeded in banishing poverty (Hussain, 2007). The extensive review suggests that there are strong linkages between irrigation and poverty (Hussain and Hanjra, 2004; Latif, 2007). Multicriteria decision making models are developed for irrigation planning and irrigation scenarios are used to show the impact of different irrigation management (Max et al., 2009). Ortega et al. (2005) have discussed Irrigation Advisory Service for farmers. They have upgraded 
farmer's capacities and awareness thus minimizing the negative environmental impacts of irrigation. According to Zarghaami (2006) effective water management requires a comprehensive consideration of all related aspects, e.g., technical, social, environmental, institutional, political and financial. Water resources management is essential for sustainable agriculture in a climate of water scarcity (Ashraf et al., 2007; Khalkheili and Zomani, 2009). In this regard, water supply system is of great importance among hydrosystems, being built and operated to provide enough water to consistently meet the demands (Brookshire and Whittington 1993; Lee et al. 2000; Mousavi and Ramamurthy, 2000). Due to the ecological, financial and environmental reasons, ecologically sustainable management of water supply systems is imperative in order to provide continuous and stable operation in meeting water demands not only by human society, but also by various ecosystems. This requires efficiently allocating water resources, utilizing renewable water sources, adopting water conservation measures, as well as reserving sufficient water for maintaining ecological, environmental and hydrological integrity (Loucks et al., 2000; Chang, 2005; Nouri et al., 2008; 2009). One of the major challenges in the decision making of sustainable water supply is uncertainty. Such uncertainty originates from internal and external changes of water systems (Loucks, et al., 2000; Huang et al., 2005; Cai et al., 2009; 2010; Tan et al., 2010). In many developing countries, increased agricultural productivity due to irrigation from dams has significantly reduced the socioeconomic problems that consequently led to reduction in poverty. Sustainable development, conservation and management of water resources are the key to increase food production and to reduce poverty in arid and semiarid countries. Good governance and monitoring are the key tools by which these impacts may be enhanced or alleviated. Stakeholders in development process sometimes act as though the elimination of poverty and economic growth are distinct from environmental goals. Where environmentally sustainable requirements have been identified, they are rarely fully integrated into the economic development and sector policies even where they make obvious economic sense. Schoups et al. (2006) investigated some strategies. These strategies included conjunctive management of surface water and groundwater resources, and engineered improvements (Abbaspour et al., 2009; Calvache et al., 2011). In the past, emphasis was on construction of dams by the investors without any environmental consideration, however, since the last years, the effects of dams on population and the environment have become under greater scrutiny. In fact, the contribution and need of dams for sustainable development cannot be denied in arid and semiarid regions. Objection on construction of large dams has become a fashion of the day merely because of few adverse impacts which are more highlighted, whereas the positive ones are ignored. Overall objective of this study was to analyze the impact of irrigation water supply from a dam on poverty reduction using a set of indicators. Specific objective was to collect, analyze and compare the pre-project (baseline) and post project data to underline the changes, both positive and negative in the biophysical and socioeconomic conditions. Development of proposed guidelines for sustainable development for poverty reduction and empowerment is another effort of this study. These guidelines may help the policy makers to achieve the Millenium development goals (MDGs) in arid countries. There are many international agencies, organizations and institutions which have provided methodologies for operation and management of the projects to overcome the poverty. For example, the United Nation's (UN) subcommittee on poverty alleviation for Asia and the Pacific has made various actions through United Nations work program to mitigate the rural poverty (UN, 2000, 2001). These programs were generally focused on poverty alleviation, food security and sustainable agricultural development through advisory services, training, information dissemination and exchange of experiences. International Institute for Sustainable Development, developed a model for poverty alleviation identifying five stakeholders consisting of: community, family, individuals, private and public sectors (Duraiappah, 2000). Similarly Asian Development Bank (ADB) developed a methodology for rural poverty alleviation in China. In this methodology various indicators were considered for reduction of poverty. The MDGs is another program which follows up eight goals to reduce the poverty by 2015. Experience elsewhere shows that bringing appropriate institutional changes into disrupted water management coupled with required capacity building of the newly established participatory institutions, can be crucial in bridging the gap for reduction of poverty (Yakubov, 2007).

\section{Sustainable development indicators}

Sustainable development is defined as the development 
Which meets the needs of present generation while not compromising the ability of future generations to meet their needs. Specific indicators called Sustainable development indicators (SDI) are often used as quantitative and qualitative measures to provide information for decision making including management and daily life decisions. An indicator may be defined as 'a parameter which gives information about some system'. In line with this description, it may be stated that all the indicators present specific information of the system under consideration. The reason of selecting these indicators was that they measure the performance of the projects and the same have been used and recommended in many studies. Human activities having severe negative impacts on the planet would be unsustainable if they continue unchecked. To avoid unsustainably, it is important to design a sustainable development framework to answer the two questions: what we are trying to assess? And what is the dimension of sustainability for any developed activity?

The concept of sustainable development received its first major international recognition in 1972 at the UN conference on Human Environment, held in Stockholm and it continued by Brundtland commission in 1983 which defined the sustainable development as the "development which meets the needs of the present (generation) without compromising the ability of future generations to meet their own needs". Rio de Janeiro conference in 1992 and its recognition is articulated in chapter 40 of agenda 21 , which calls on countries at the national as well as international levels, governmental and non-governmental organizations to develop and identify the indicators of sustainable development which should provide a solid basis for decision making at all levels. More recently, the World Summit on Sustainable Development was held in Johannesburg in 2002 to assess the progress since the Rio conference. The development in sustainable development indicators is a continued process and these indicators were updated in MDGs by the UN in 2005. Some of these indicators were modified in the present study to suit the conditions in developing countries in general and particularly in Iran (Table 1).

\section{Impacts of large dams on the environment}

The impacts of large dams on environment have been studied by many organizations and researchers. The World Commission on Dams (WCD), 2000 made an excellent effort to analyze the performance of large dams including their environmental and social impacts. Results of this study revealed that majority

Table 1: The selected indicators

\begin{tabular}{|c|c|c|}
\hline Theme & Sub-theme & Indicator \\
\hline $\begin{array}{l}\text { Population } \\
\text { education }\end{array}$ & $\begin{array}{l}\text { Population change } \\
\text { education level }\end{array}$ & $\begin{array}{l}\text { Population growth rate } \\
\text { *Impact on literacy rate in downstream area } \\
\text { Development of educational center at downstream }\end{array}$ \\
\hline Housing & $\begin{array}{l}\text { Living condition } \\
\text { decentralization } \\
\text { land, }\end{array}$ & $\begin{array}{l}\text { Floor area per person, proportion of population living in slums, percent of new } \\
\text { communities, villages and towns grew after construction of the dam } \\
\text { Percent of land coverage or use prior to dam construction }\end{array}$ \\
\hline $\begin{array}{l}\text { Natural } \\
\text { resources }\end{array}$ & $\begin{array}{l}\text { Irrigation and command } \\
\text { area development }\end{array}$ & $\begin{array}{l}\text { *Agriculture type at downstream of the dam, maximum irrigated command area } \\
\text { achieved compared to the target. Achievement of irrigation development }\end{array}$ \\
\hline industries & $\begin{array}{l}\text { Water sector drinking } \\
\text { water }\end{array}$ & $\begin{array}{l}\text { *Industries development in area due to dam construction } \\
\text { Population with access to safe drinking water }\end{array}$ \\
\hline Health & $\begin{array}{l}\text { Sanitation } \\
\text { healthcare delivery }\end{array}$ & $\begin{array}{l}\text { Proportion of population with access to improved sanitation } \\
\text { Large dams infectious diseases }\end{array}$ \\
\hline Environment & $\begin{array}{l}\text { impact due to pattern of } \\
\text { dam } \\
\text { Impact due to reservoir }\end{array}$ & $\begin{array}{l}\text { Changes in downstream hydrology: } \\
\text { a) Change in total flows } \\
\text { b) Change in seasonal flows } \\
\text { c) Change in extreme high and low flows } \\
\text { d) Changes in downstream water quality caused by altered flow pattern } \\
\text { e) Changes in downstream morphology of river bed }\end{array}$ \\
\hline Equity & Poverty & $\begin{array}{l}\text { *Percent of population living below the poverty line basd on national records of pre and } \\
\text { post- dam construction } \\
\text { * Large dams impact on poverty } \\
\text { * Creation of job opportunity due to large dams in Government and private sectors } \\
\text { * Unemployment type and rate }\end{array}$ \\
\hline
\end{tabular}




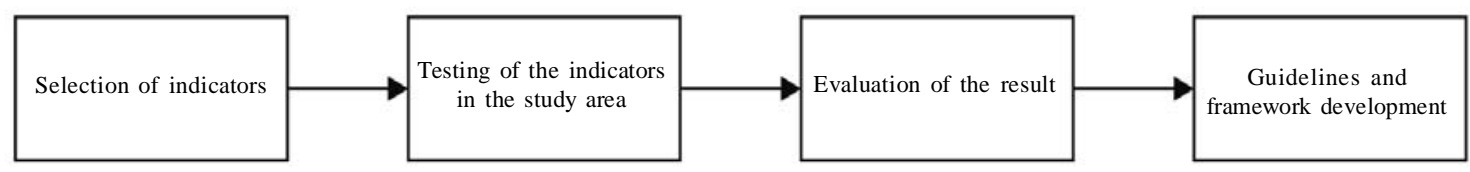

Fig. 1: Sequence of the methodology adopted for the study

of the dams continue to generate benefits beyond their projected lives. On the other hand, some of the large dams have more negative impacts rather than positive impacts on the ecosystem. This was mainly "due to lack of attention given to anticipating and avoiding the impacts; the poor quality and uncertainty of predictions; the difficulty of coping with all impacts; and partial implementation and success of mitigation measures" (Brids and Wallace, 2001). One of the important reasons of not achieving the targeted performance level in some of the irrigation systems was over emphasizing the physical infrastructures, while neglecting the social dimension (Kuscu, 2008). Environmental degradation makes people poorer through the lack of availability of natural resources, and natural resources management should include the full participation and cooperation of local residents with government to ensure socioenvironmentally sustainable resource management (Manzor et al., 2010). The pressure of human population and patterns of development, frequently jeopardize the integrity of worldwide river systems. In such cases, an Integrated water resources management (IWRM) approach is essential, as presented recently by Doummar et al. (2009). In the past emphasis was on dam construction by investors without any environmental consideration, however since the last years, the effects of dams on population and the environment have come under greater scrutiny by the investors. In fact, the contribution and need of dams for sustainable development, especially in arid and semiarid regions cannot be denied.

\section{MATERIALS AND METHODS}

Both quantitative and qualitative methods were used to collect data for this study from various organizations i.e., government agencies and corporations both domestic and international. A thorough review of national and international works done on poverty reduction, sustainable development due to large dams, irrigation systems and their impacts were carried out. A comprehensive evaluation was performed based on the selected indicators (Table 1) in the command area of Minab dam in Iran. The methodology adopted in this research is depicted in Fig. 1.

\section{The study area}

The study area is located in the south eastern province of Hormozgan, Iran about $35 \mathrm{~km}$ from the Persian Gulf. Minab is the nearest town to the dam site after which the name of the dam is attributed. This area was the most poverty stricken before construction of the dam. Minab river is one of the most important rivers in southern Iran and it originates from the southern slopes of Kerman mountains. The dam serves as the main source of water supply in the plains of Minab. Completion of Minab dam dates back to 1983 and its complimentary irrigation and drainage networks were completed by 1986 . It brought a drastic change in the socioeconomic conditions in the area. The irrigation system also triggered tube well irrigation and sanitation services in the area which has a fertile soil and suitable climate with two distinct cropping seasons, i.e., Winter and Summer, each well marked and separated by dry season for crop maturity and harvesting. Narrow river plains contain well drained deep, medium textured, moderately calcareous and salt free soils which are very fertile. Good soils in presence of water, have a high potential for agriculture. In this study, northern irrigation canal command area was selected as an example.

\section{Data collection}

Data collection was carried out in two steps: 1) Collection of historical data from different departments and organizations; and 2) Fieldwork for primary data collection through interviews and discussions with the stakeholders in the study area. The following data were collected from different organizations for the years 1982 to 2006.

- Population: Statistical Center of Iran, related local offices and filed visits. 
- Education: Statistical Center of Iran, Management and Programming Organization, Hormozgan, filed visits and interviews.

- Housing: Statistical Center of Iran, Field visits, Management and Programming Organization, previous studies in the area.

- Natural resources: Agricultural Economics Research Center of Iran, Ministry of Jihad Agriculture of Iran, previous studies in the area (Barkhordari, 2003).

- Industries: Field visits, Management and Programming Organization of Iran, Iranian National Geographical Organization.

- Health: Shahid Muhammadi Hospital -Hormozgan, Heath Center (Statistical data about disease in the study area).

- Environment: Synoptic station of Minab (Hydrological data of various years), Ministry of Energy - Iran (inflow outflow data of Minab dam of various years), Hormozgan Regional Water Resources Landsat Satellite images, Related environmental workshops in the area.

- Equity: United Nations Development Programme (UNDP) documents (Isfahani, 2007), Iranian Central Bank publications.

\section{RESULTS AND DISCUSSION}

Irrigated area and crop yield

Landsat images of years 1989 and 2001 are shown in Figs. 2 and 3 respectively. The red color of the chlorophyll indicates healthy green vegetation in these figures. The first figure presents the information after a few years of commissioning of the dam. The irrigation system in 1989 (canals and farm channels) was not completely developed. Moreover, the farmers were not fully aware of making efficient use of irrigation water. Therefore, the irrigated crop land is much less than the year 2001. Data collected from the study area clearly indicates that the irrigated area has almost doubled (about 6000 ha) in year 2006 as compared to the cultivated land before construction of the dam. It is worth mentioning here that yield of fruitful trees and vegetables have increased manifolds by irrigation from the dam as given in Table 2. Agricultural products of this area reach to the markets 40 days earlier compared to other parts of the country due to special location of the area. Thus, farmers earn extra benefits from early ripening of their farm produce. Additionally, the farmers made extra efforts to obtain more advantage from their irrigated land by changing the cropping pattern, increasing the cropping intensity and crop yields.
Socioeconomic conditions and availability of services

Based on screening of the impacts and effects of irrigation from the dam on the biophysical and socioeconomic environments of the area, the impacts on poverty reduction are summarized in Table 3 . According to this data it can be concluded that the dam has positive impacts on all the parameters which play an important role in poverty reduction in the study area.

According to the census of 2006 and field visits conducted for this study, there were evident distinctions in various sectors in the area compared to the conditions before construction of the dam (Table 4). Evidently, there is substantial improvement in basic services, such as education, health, water supply, employment, accessibility and others amenities. For example, the literacy rate in rural area before dam construction was $41 \%$ which increased to $74 \%$ in 2006. Similarly, opportunities for jobs in government and private sectors increased approximately $2.5 \%$ and $23 \%$, respectively in 2006 . These values were 9-10\% in private sector and negligible in the government sector before 1983. Job opportunities in private sector were recorded to be $19.6 \%$ in 1996.

\section{Comparison of the objectives achieved}

A summery of primary goals of the project along with their to-date achievement is presented in Table 5. This data revael that some of the objectives have been met, whereas no significant achievements were made in the others.

Application of the indicators in the study area showed lack of: 1) interdisciplinary knowledge among various organizations with respect to their duties; 2) social organizations for promotion of technical and institutional skills; and 3) capacity building programs in social and engineering sectors. These factors have caused low progress towards achievement of the primary objectives of the project. Furthermore, lack of cooperation between the national and international organizations as well as lack of knowledge for sustainable development and relevant experiences making obstacles for meeting the objectives of project development. Similar examples can be cited from Pakistan of the large scale Salinity Control and Reclamation Projects (SCARP). These projects were greatly effective in lowering the water table, whereas did not fully meet their planned objectives (Awan and 


\section{A. A. Irajpoor; M. Latif}

Latif, 1984; Latif and Zaman, 1998). The results of other studies also emphasize on such aspects as summarized in Table 6 in Tanzania. From the above discussion it is apparent that normally the targeted goals and objectives are not often fully achieved in irrigation related projects in different countries. A methodology is proposed in the next section to overcome the deficiency based on available organizations in developing countries.

\section{Proposed framework for targeted development}

Achievement of primary objective of projects after many years of their completion is the basic idea of this framework. The proposed framework consists of four

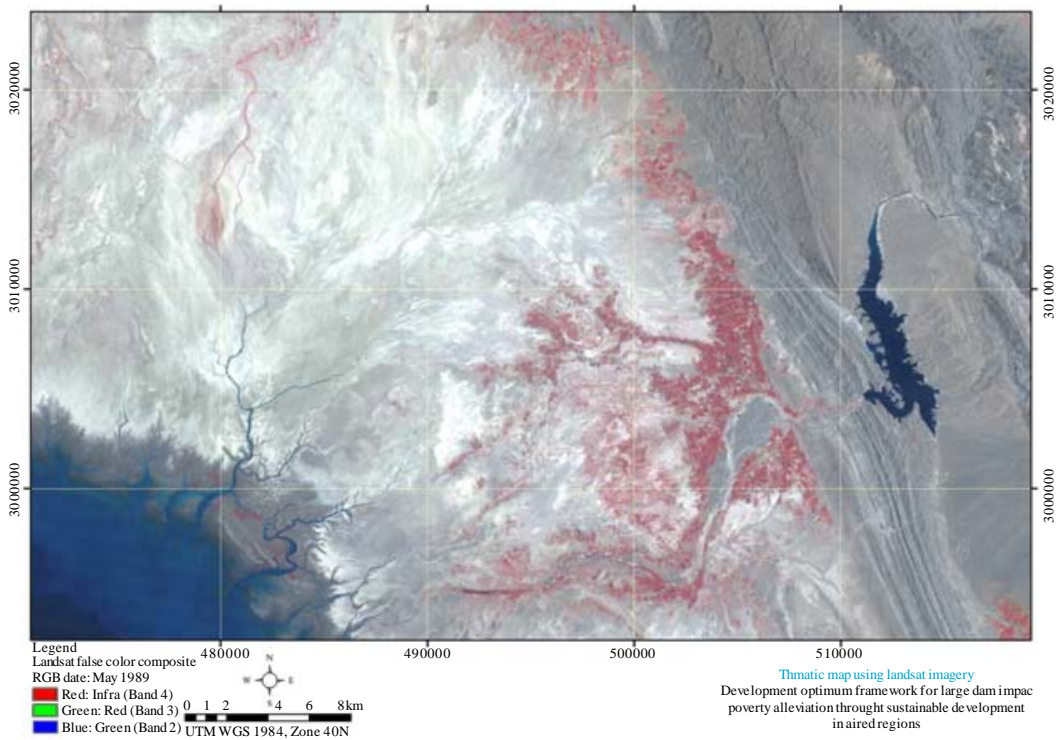

Fig. 2: Landsat imagery of the study area (Minab dam -1989)

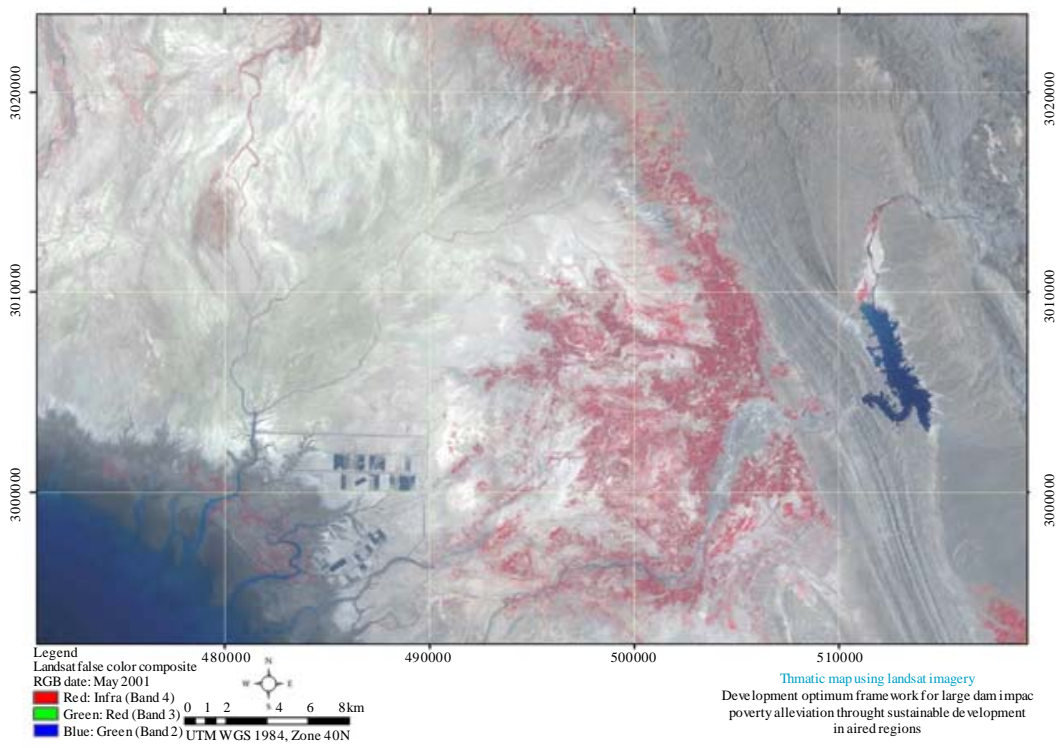

Fig. 3: Landsat imagery of the study area (Minab dam - 2001) 
layers namely: 1) Base line; 2) Synthesis; 3) Action areas; and 5) Outcome (Fig. 4). Goals of each activity are summarized in Table 7 while their explanation is as follow:

The base line is a sine qua non for execution and clear understanding of the ongoing phenomena based on adequacy and authenticity. Legal support in any activity cause promotion and provides the acceleration towards the desired action. The second layer of this framework, which is called syntheses action towards sustainability, would be optimum by evaluation of beneficial and adverse impacts. These impacts will be monitored based on their sensitivity in the study area through social and engineering organizations with respect to the responsibilities of various organizations. To have better concept of this methodology, a strategy can be designed to show the impacts in various stages of the project as explained below:

- Natural condition: In this stage, no activity is visible and natural condition of an area is going on the variable $\mathrm{P}_{0}$ having initial condition designed as $\mathrm{T}_{0}$ and $\mathrm{I}_{0}$ which states the area without project $\left(\mathrm{P}_{0}\right)$ at zero time $\left(\mathrm{T}_{0}\right)$ and zero impact $\left(\mathrm{I}_{0}\right)$.

- Commencement: In this stage, project $\left(\mathrm{P}_{1}\right)$ started at time $\mathrm{T}_{1}$ and having impact as $\mathrm{I}_{1}$.

- Completion: In this stage, completion time of the project is considered as $T_{n}$ with impact $I_{n}$ in time $T_{n}$. All the three steps are shown in Fig. 5.

Evaluation of the above conditions involved in any development project, emphasizing that impacts are sine qua non phenomena. The activity of impacts can be identified through the time consideration $\left(\mathrm{T}_{0}, \mathrm{~T}_{1}\right.$ and $\left.\mathrm{T}_{\mathrm{n}}\right)$

Table 2: Yields of date-palm and different vegetable crops in the study area

\begin{tabular}{lccc}
\hline Year & 1982 & 2006 & Yield increase \\
Crop & Pre-dam construction (kg/ha) & Post-dam construction (kg/ha) & 4000 \\
\hline Date & 2000 & 14000 & 367 \\
Citrus & 3000 & 10000 & 233 \\
Onion & 3000 & 15000 & 114 \\
Egg Plant & 7000 & 12000 & 140 \\
Cucumbers & 5000 & 3000 & 200 \\
Pepper & 1000 & 15000 & 200 \\
Melon & 5000 & 18000 & 200 \\
Tomato & 6000 & & \\
\hline
\end{tabular}

Table 3: Beneficial impacts of dam construction and irrigation on agriculture, livestock, education, health, socioeconomic and environment

\begin{tabular}{|c|c|c|}
\hline No. & Active phenomena & Result \\
\hline \multicolumn{3}{|c|}{ Agricultural and livestock } \\
\hline 1 & Conversion from rainfed to irrigated land & Drastic increase in agricultural produce and crop yield \\
\hline 2 & Flood damage prevention & Reduce flood losses and reduced runoff in high rainfall periods \\
\hline 3 & Increase in irrigated land & Significant increase in production \\
\hline 4 & Multiple crops and increased cropping intensity & Rising in income and poverty reduction \\
\hline 5 & New market & People participation and economic development \\
\hline 6 & $\begin{array}{l}\text { Pasture management and conservation strategies } \\
\text { Education and health }\end{array}$ & Improved livestock and its produce \\
\hline 7 & Increase educational centers & Increase of knowledge and literacy rate. \\
\hline 8 & Health center availability & Safety and improvement in quality of life \\
\hline 9 & Availability of electricity & Providing more facilities and improve life quality. \\
\hline 10 & Water treatment & Improve life quantity and sanitation \\
\hline 11 & Modification in road & Increase accessibility \\
\hline \multicolumn{3}{|c|}{ Socioeconomic } \\
\hline 12 & Increase in economic activity & Increase in income \\
\hline 13 & Job creation & More job opportunity \\
\hline 14 & Increase in transportation & Increase in rural activities \\
\hline 15 & Ecotourism & Increase and development in rural facility \\
\hline 16 & Modification in road & Increase accessibility. \\
\hline \multicolumn{3}{|c|}{ Environment } \\
\hline 17 & Availability of water in reservoir & Life security for fauna and flora at down stream \\
\hline 18 & Increased groundwater for recharge & Drought mitigation and thus improve the environment \\
\hline
\end{tabular}


in project area using various impact prediction models. This can be stated as:

$\mathrm{I}=\Sigma \mathrm{d}+\Sigma \mathrm{i}$ Where: $\mathrm{I}=$ Total Impacts, $\mathrm{Id}=$ Direct Impact and Ii = Indirect Impact

The syntheses layer in Fig. 4 reveals that the main effort is to manage the already identified impacts along with the project goals through social and engineering organizations. Some of these main organizations categorized in social and engineering sectors are listed in Table 8 along with their responsibilities.

\section{Sustainable project organization}

In the action layer in Fig. 4, a permanent organization namely Sustainable Project Organization (SPO) is proposed that should work and coordinate with various organizations in the

Table 4: Availability of services during pre- and post construction of the dam in percent

\begin{tabular}{|c|c|c|c|c|c|}
\hline \multirow[b]{2}{*}{ Services } & \multicolumn{2}{|c|}{ Year } & \multirow[b]{2}{*}{ Services } & \multicolumn{2}{|c|}{ Year } \\
\hline & 1982 & 2006 & & 1982 & 2006 \\
\hline Primary school & 40 & 90 & Bank & 0 & 20 \\
\hline Guidance school & 10 & 80 & General transport services & 0 & 60 \\
\hline High school & 10 & 40 & Grocery & 10 & 90 \\
\hline NGO & 0 & 100 & Public bath room & 30 & 0 \\
\hline Mosque & 80 & 100 & Public health center & 0 & 80 \\
\hline Agricultural extension & 0 & 20 & Doctor & 0 & 20 \\
\hline Utility store & 40 & 60 & Midwife & 0 & 60 \\
\hline Water supply system & 30 & 100 & Health technician & 0 & 80 \\
\hline Electricity service & 10 & 100 & Veterinarian & 0 & 10 \\
\hline Post office & 0 & 20 & Asphalt road & 10 & 90 \\
\hline Public call office & 10 & 30 & Industries & 0 & 40 \\
\hline Literacy rate & 41 & 74 & & & \\
\hline
\end{tabular}

Source: Statistical Center of Iran 1982-2006

Table 5: Summery of the primary objectives achieved as compared to the targets in the study area

\begin{tabular}{|c|c|c|c|}
\hline No. & Proposed (Targeted) goals & Status (2005-2006) & Remarks \\
\hline \multirow[t]{2}{*}{1} & $\begin{array}{l}\text { Agricultural production: } \\
\text { Crop and citruses production about } \\
280,000 \text { tons/year. }\end{array}$ & $\begin{array}{l}\text { Maximum production of } 130,000 \\
\text { tons was recorded in year } 1975 .\end{array}$ & $47 \%$ of primary goals fulfilled \\
\hline & $\begin{array}{l}\text { Supply of crops for use within the } \\
\text { country and for export abroad }\end{array}$ & There was no tangible progress. & $\begin{array}{l}\text { The increase in crop produce was } \\
\text { consumed locally }\end{array}$ \\
\hline 2 & $\begin{array}{l}\text { Area under cultivation : } \\
\text { Net area under cultivation } 10821 \text { ha }\end{array}$ & 6000 ha & $57 \%$ of primary goal met. \\
\hline 3 & $\begin{array}{l}\text { Irrigation water of } 210 \text { million cubic } \\
\text { meters (MCM) }\end{array}$ & Low & $\begin{array}{l}\text { Record shows that this value fluctuated } \\
\text { e.g. in year 1996-97 the amount of } \\
\text { delivered water to the farmers was } \\
\text { recorded about } 91-144 \text { MCM or in } \\
\text { average of } 120 \text { MCM.That is about } 57 \% \\
\text { of targeted objectives. }\end{array}$ \\
\hline \multirow[t]{4}{*}{4} & $\begin{array}{l}\text { Operation and maintenance of } \\
\text { irrigation structures for development } \\
\text { in Minab plain area : }\end{array}$ & $\begin{array}{l}\text { Management of irrigation is by } \\
\text { Minab Roud Company monitored } \\
\text { by the regional water company of } \\
\text { Hormozgan }\end{array}$ & $\begin{array}{l}\text { There is no professional management for } \\
\text { water distribution through the network }\end{array}$ \\
\hline & $\begin{array}{l}\text {-Agriculture training } \\
\text { - New crop introduction }\end{array}$ & $\begin{array}{l}\text { Jihad Agriculture is responsible } \\
\text { for new products } \\
\text { No notable progress }\end{array}$ & $\begin{array}{l}\text { Development of new products in area } \\
\text { like Mangoes and Bannas started after } \\
14 \text { years of dam commissioning }\end{array}$ \\
\hline & $\begin{array}{l}\text { Development of new irrigation } \\
\text { methods and abandoning of } \\
\text { traditional irrigation methods. }\end{array}$ & No notable progress achieved & \\
\hline & $\begin{array}{l}\text { Adoption of mechanized land } \\
\text { operation }\end{array}$ & & \\
\hline
\end{tabular}


Int. J. Environ. Sci. Tech., 8 (3), 533-544, Summer 2011

Table 6: Important points identified by problem analysis for irrigation projects and their main causes in Tanzania

\begin{tabular}{lc}
\hline \multicolumn{1}{c}{ Important points } & Main cause \\
\hline Lack of appropriate participatory approaches like PRA (Participatory rural appraisal) and RRA & Lack of sociological consideration \\
(Rapid rural appraisal) & Lack of technical consideration \\
Unsound logical structure of project and weak linkage between purpose and output of the & Lack of technical knowledge \\
project & Lack of technical and institutional \\
Misunderstanding of the concept of "by simple and low-cost technology”, taken to mean "easy & consideration \\
and no without technical know-how” & lack of technical knowhow \\
$\begin{array}{l}\text { Lack of feedback system on the lessons learnt through actual experience in implementation of } \\
\text { the irrigation projects }\end{array}$ & Lack of sociological and technical \\
Inadequate guidelines and manuals for planning, design and construction supervision, and lack \\
of their proper applications.
\end{tabular}

Source: Ministry of Agriculture, Food and Cooperatives, Tanzania 2002

Table 7: Description of the proposed framework

\begin{tabular}{|c|c|c|c|}
\hline Layer & $\begin{array}{l}\text { Organizations to be involved } \\
\text { (national and international) }\end{array}$ & $\begin{array}{l}\text { Related studies and experiences } \\
\text { (national and international) }\end{array}$ & Goals \\
\hline \multirow{2}{*}{ Base line } & $\begin{array}{l}\text { United Nations, } \\
\text { International Bank, }\end{array}$ & \multirow{2}{*}{$\begin{array}{l}\text { Poverty alleviation, sustainable } \\
\text { development, } \\
\text { Constitutional law of the country }\end{array}$} & \multirow{2}{*}{$\begin{array}{l}\text { To provide the sustainable development } \\
\text { concepts for persons or governmental } \\
\text { organizations or NGOs for action towards } \\
\text { poverty alleviation for the projects }\end{array}$} \\
\hline & $\begin{array}{l}\text { GO and NGOs, Universities and } \\
\text { Scholars }\end{array}$ & & \\
\hline Synthesis & $\begin{array}{l}\text { Department of Environment, } \\
\text { Social and Engineering } \\
\text { Organization }\end{array}$ & Environmental impact assessment & $\begin{array}{l}\text { To manage beneficial and adverse } \\
\text { impacts of the project in sustainable } \\
\text { manner by use of concern social and } \\
\text { engineering organization }\end{array}$ \\
\hline Action area & $\begin{array}{l}\text { Capacity building and training } \\
\text { center, Concern Ministries and } \\
\text { NGOs }\end{array}$ & $\begin{array}{l}\text { Institutional concept for } \\
\text { sustainable management }\end{array}$ & $\begin{array}{l}\text { Capacity building Development and } \\
\text { people participation for performance of } \\
\text { primary objective of project }\end{array}$ \\
\hline Outcome & $\begin{array}{l}\text { Sustainable Project Organization, } \\
\text { Monitoring and Accountability } \\
\text { office, Human Right } \\
\text { Representative Monitoring Office }\end{array}$ & $\begin{array}{l}\text { Institutional concept for } \\
\text { sustainable management }\end{array}$ & $\begin{array}{l}\text { Sustainable management of project } \\
\text { through cooperation of the society, NGOs } \\
\text { and GOs for poverty alleviation }\end{array}$ \\
\hline
\end{tabular}

Table 8: Responsibilities of proposed social and engineering organizations

\begin{tabular}{|c|c|c|c|}
\hline No. & Organization & Category & Responsibility \\
\hline 1 & Legislation / social security office & Social & $\begin{array}{l}\text { To save the right of society specially manpowe } \mathrm{r} \text { / providing the } \\
\text { legal welfare / monitoring the rights between governmental and } \\
\text { private sectors }\end{array}$ \\
\hline 2 & Health Management services & Social & $\begin{array}{l}\text { To provide health facility and manage spreading of diseases } \\
\text { due to existence of the project }\end{array}$ \\
\hline 3 & Transportation services & Social & $\begin{array}{l}\text { To facilitate goods and personnel transportation and related } \\
\text { welfares }\end{array}$ \\
\hline 4 & $\begin{array}{l}\text { Surfaces and Groundwater user } \\
\text { associations }\end{array}$ & Social & $\begin{array}{l}\text { To provide people participation / water right / cooperation } \\
\text { between private and governmental organizations }\end{array}$ \\
\hline 5 & Social Cooperation Center & Social & $\begin{array}{l}\text { To provide participation circumferences for individuals and } \\
\text { NGOs and others }\end{array}$ \\
\hline 6 & MIS/GIS/Land record organization & Technical & $\begin{array}{l}\text { To save and secure the land property in government and } \\
\text { private sectors; To eliminate dispute of property between that } \\
\text { society; To establish a data base }\end{array}$ \\
\hline 7 & Environmental organization & Technical & To protect the environment \\
\hline 8 & Water resources organization & Technical & $\begin{array}{l}\text { To protect quantity and quality of water and promote } \\
\text { cooperation with regional water company in the area. }\end{array}$ \\
\hline 9 & Soil management organization & Technical & $\begin{array}{l}\text { To monitor the quality and quantity of soil; To develop the soil } \\
\text { in that area and to help farmers for better crops }\end{array}$ \\
\hline 10 & $\begin{array}{l}\text { Road development and maintenance } \\
\text { office }\end{array}$ & Technical & $\begin{array}{l}\text { For development of roads and their maintenance in the project } \\
\text { area }\end{array}$ \\
\hline
\end{tabular}


project area. These government organizations and NGOs may act with the SPO and there should be at least one representative of each in SPO (Table 8). The SPO will bridge between the government organizations and the beneficiaries. The SPO will improve irrigation network through capacity building and by cooperation with main social, technical and engineering organizations. This would make cooperation among all the stakeholders in the project area. Also concerned ministries and some NGOs will liaison with the SPO. Monitoring by the SPO may provide the sustainable development in the project area which might help to reduce poverty.

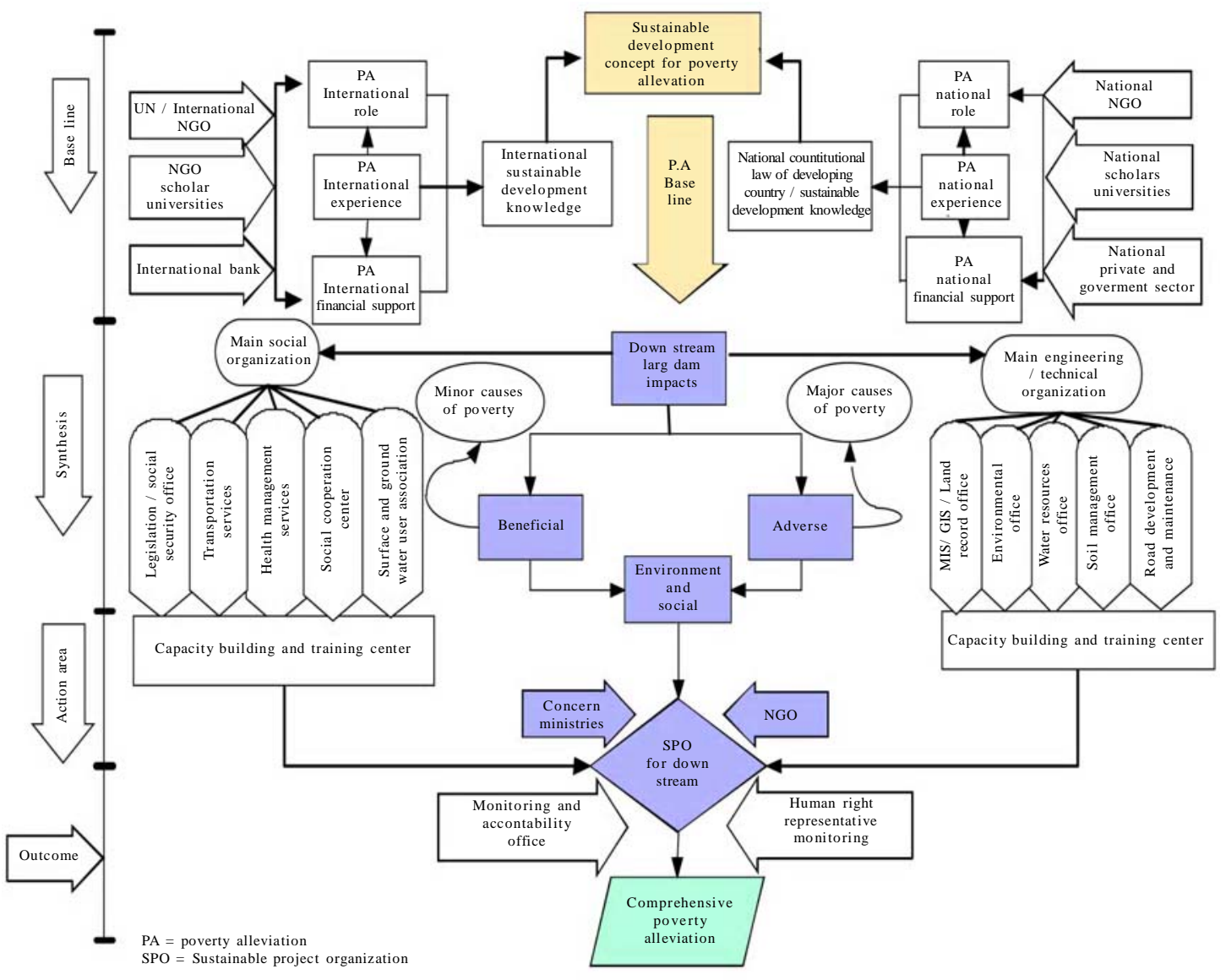

Fig. 4: Institutional framework for poverty reduction for dams and irrigation projects in developing countries

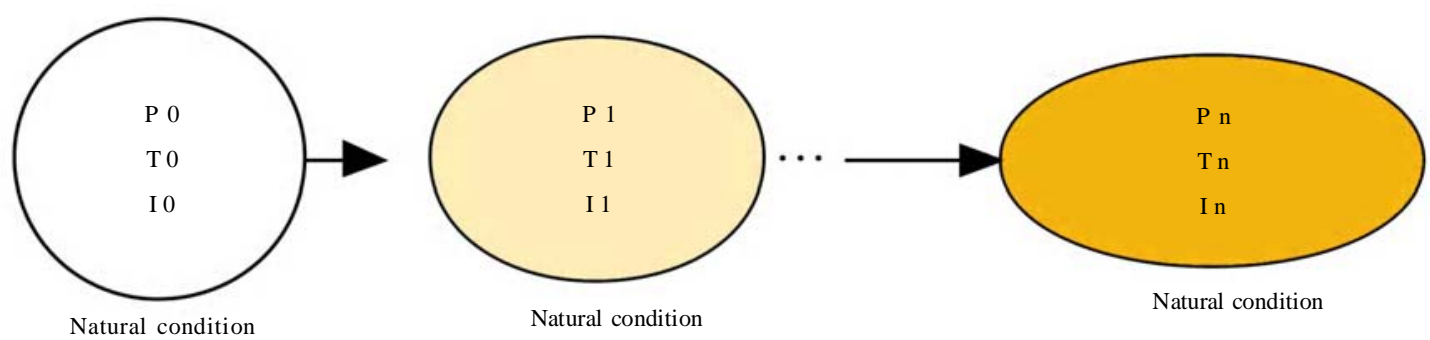

Fig. 5: Impacts of without $\left(\mathrm{P}_{0}\right)$ project and with project $\left(\mathrm{P}_{1}\right.$ and $\left.\mathrm{P}_{\mathrm{n}}\right)$ 


\section{CONCLUSION}

Landsat images of 1989 and 2001 given in Fig. 1 and 2 present developments in agriculture in the study area due to irrigation. There is significant increase in cropping intensity, crop yield and irrigated area after constructing the irrigation network of the dam. Socioeconomic conditions have improved due to development in agriculture as a result of irrigation from the dam. The literacy rate increased to $74 \%$ in 2006 which was $41 \%$ before construction of the dam. Similarly, job opportunities and quality of life increased due to availability of various services leading to reduction in poverty from $15 \%$, before construction of the dam, to $7.3 \%$ by the year 2006. These results clarify that impacts of the dam construction though being significantly positive, are not the same as the targeted objectives envisaged in the feasibility report of the project. The results of this study showed that there is only $50-60 \%$ achievement in some of the planned objectives, while no notable progress was observed in the others. Lessons learned from this study may support other similar studies which lack the cooperation and management in various organizations and also form a basis for less developed water resources projects. The institutional framework proposed in this study, aims to strengthen the management of water resources projects by involving social and technical organizations.

\section{ACKNOWLEDGEMENTS}

The authors wish to appreciate all organizations that provided data for the study, especially Statistical Center, Management and Programing Organization, Agricultural Department, Central Bank and Hormozgan Regional Water Company in Iran. The authors are also grateful to the anonymous reviewers whose comments have helped us to improve the manuscript.

\section{REFERENCES}

Abbaspour, M.; Mirbagheri, S. A.; Monavvari, M.; Javid; A. H.; Zarei, H., (2009). Conceptual hydrosalinity model for prediction of salt load from wastewater flows into soil and ground water. Int. J. Environ. Sci. Tech., 6 (3), 359-368 (10 pages)

Ashraf, M. A.; Kahlown; A. Ashfaq., (2007). Impact of small dams on agriculture and groundwater development: A case study from Pakistan. Agri. Water Manag., 92 (1-2), 90-98 (9 pages).

Awan, N. M.; Latif, M., (1984). Organizational and management aspects of salinity control and reclamation project No. 1 in Pakistan. Proceedings of the $12^{\text {th. }}$ Congress on Irrigation and Drainage, International Commission on Irrigation and Drainage, Fort Collins, U.S.A.

Barkhordari, J., (2003). Assessing the effects of land use change on the hydrologic regime by RS and GIS. A case study in the Minab Catchment. M.Sc. Thesis, International Institute for Geoinformation Science and Earth Observation, Hormozgan province, Iran.

Birds, J.; Wallace, P., (2001). Dams and development - an insight to the report of the world commission on dams. J. of Irrigat. and Drain. ICID., 50 (1), 53-64 (12 pages).

Brahim, N.; Blavet, D.; Gallali, T.; Bernoux , M. (2011). Application of structural equation modeling for assessing relationships between organic carbon and soil properties in semiarid Mediterranean region. Int. J. Environ. Sci. Tech., 8 (2), 305-320 (16 pages).

Brookshire, D. S.; Whittington, D., (1993). Water resources issues in the developing countries. Water Resour. Res., 29 (7), 1883-1888 (6 pages).

Cai, Y. P.; Huang, G. H.; Lin, Q. G.; Nie, X.H.; Tan, Q., (2009). An optimizationmodel- based interactive decision support system for regional energy management systems planning under uncertainty. Expet. Syst. Appl., 36 (2), 3470-3482 (12 pages).

Cai, Y. P.; Huang, G. H.; Tan, Q.; Chen, B., (2010). Identification of optimal strategies for improving ecoresilience to floods in ecologically vulnerable regions of a wetland. Ecol Model., 222 (2), 360-369 (10 pages).

Calvache, M. L.; Duque, C.; Gomez Fontalva, J. M.; Crespo, F., (2011). Processes affecting groundwater temperature patterns in a coastal aquifer. Int. J. Environ. Sci. Tech., 8 (2), 223-236 (14 pages).

Chang, N. B., (2005). Sustainable water resources management under uncertainty. Stoch. Environ. Res. Risk Assess., 19 (2) 97-98 (2 pages).

Dikinya, O.; Areola, O. (2010). Comparative analysis of heavy metal concentration in secondary treated wastewater irrigated soils cultivated by different crops. Int. J. Environ. Sci. Tech., 7 (2), 337-346 (10 pages).

Doummar, J.; M.A. Massoud; R. Khoury; M. Khawlie., (2009). Optimal water resources management: Case of lower Litani River, Lebanon. Water Res. Manage., 23 (11), 2343-2360 (18 pages).

Duraiappah, A. K., (2000). Sustainable development and poverty alleviation exploring the links alleviating poverty: five decades of under-achievement. International Institute for Sustainable Development.

FAO, (2011). Low income food -deficit countries (LIFDC): Food and Agriculture Organization. Country Profiles and Mapping Information, USA.

Huang, G. H.; Linton, J. D.; Yeomans, J. S.; Yoogalingam, R., (2005). Policy planning under uncertainty: Efficient starting populations for simulation-optimization methods applied to municipal solid waste management. J. Environ. Manag., 77 (1), 22-34 (13 pages).

Hussain, I., (2007), Pro-poor intervention strategies in irrigated agriculture in Asia: Issues, lessons, options and guideline. J. Irrigat. Drain., 56 (2-3), 119-126 (8 pages).

Hussain, I.; Hanjir, A. M., (2004). Irrigation and poverty alleviation: review of the empirical evidence. J. Irrigat. Drain., 53 (1), 1-15 (15 pages).

Isfahani, D., (2007). Poverty, inequality, and populist politics in Iran. Department of Economics Virginia Tech Version. 
Khalkheili, T. A.; Zamani, G. H., ( 2009). Farmer participation in irrigation management: The case of Doroodzan Dam Irrigation Network, Iran. Agri. Water Manage., 96 (5), 859865 (7 pages).

Kuscu, H., (2008). An assessment of the irrigation management transfer program: case study in the Mustafakemalpasa irrigation scheme in Turkey. J. Irrigat. Drain., 57 (1), 1522 (8 pages).

Latif, M., (2007). Spatial productivity along a canal irrigation system in Pakistan. J. Irrigat. Drain., 56 (5), 509-521 (13 pages).

Latif, M.; Zaman, W., (1998). Constraints and main issues of irrigation system in the Indus Basin of Pakistan. J. Drain. Water Manage., 2 (2), 1-11 (11 pages).

Lee, Y. W.; Bogardi, I.; Kim, J. H., (2000). Decision of water supply line under uncertainty. Water Resour. Res., 34 (13), 3371-3379 (9 pages).

Loucks, D. P.; Stakhiv, E. Z.; Martin, L. R., (2000). Sustainable water resources management. J. Water Resour. Plann. Manag., 126 (2), 43-47 (5 pages).

Manzoor, E.; Chowdhury, S. A., (2010). Poverty-environment nexus: an investigation of linkage using survey data. Int. J. Environ. Sustain. Develop., 9 (1-3) 91-113 (23 pages).

Marco, M.; Dorian, Q. F., (2006). Palaeoecology and the Harappan Civilisation of South Asia: Reconsideration. Quater. Sci. Rev., 25 (11-12), 1283-1301 (19 pages).

Max, B.; Karin, B.; Jose, L. A., (2009). Integrated water resources management for sustainable irrigation at the basin scale. Chilan J. Agri. Res., 69 (1), 69-80 (12 pages).

Ministry of Agriculture and Food Security, Government of Tanzania, (2002). Master plan report for Smainland.

Mousavi, H.; Ramamurthy, A. S., (2000). Optimal design of multi-reservoir systems for water supply. Adv. Water Resour. 23 (6), 613-624 (12 pages).

Nouri, J.; Danehkar, A.; Sharifipour, R. (2008). Evaluation of ecotourism potential in the northern coastline of the Persian Gulf. Environ. Geo., 55 (3), 681-686 (6 pages).
Nouri, J.; Fatemi, M. R.; Danekar, A.; Fahimi, F. G.; Karimi, D., (2009). Determination of environmentally sensitive zones along Persian Gulf coastlines through geographic information system. J. Food Agri. Environ., 7 (2), 718 725 ( 8 pages).

Ortega, J. F.; de Juan. J. A.; Tarjuelo., J. M., (2005). Improving water management: The irrigation advisory service of Castilla-La Mancha (Spain). Agric. Water Manage. 77 (13) 37-58 (22 pages).

Schoups, G.; Addams, C. L.; Minjares, J. L.; Gorelick., S. M., (2006). Sustainable conjunctive water management in irrigated agriculture: Model formulation nd application to the Yaqui Valley, Mexico. Water Resour. Res., 42 (10), 10417-10419 (3 pages).

Tan, Q.; Huang, G. H.; Cai, Y., (2010). Radial-interval linear programming for environmental management under varied protection levels. J Air Waste Manage. Assoc., 60 (9), 1078-1093 (16 pages).

United Nations, (2000-2001). Compendium of United Nations work programmes on rural poverty alleviation, inter-agency subcommittee on poverty alleviation for Asia and the Pacific, USA.

United Nations, (2005). Indicators of sustainable development -review and assessment -background paper. Report no. undsd/egm/isd/2005/crp.1, USA.

World Commission on Dams, Clarke C., ( 2000). Cross-check survey. Consultant to the secretariat, South Africa. Available at: http://www.swissdams.ch/Committee/Dossiers/wcd/ Large \%20 Dams \%20 Cross-Check \%2 0 Survey \% 20 \%20Main\%20Page.htm

Yakubov, M., (2007). Mainstreaming rural poor in water resources management: preliminary lessons of a bottomup WUA development approach in central Asia. J. Irrigat. Drain., 56 (2), 261-276 (16 pages).

Zarghaami, M., (2006). Integrated water resources management in Polrud irrigation system. Water Resour. Manage. 20 (2), 215-225 (11 pages).

\section{AUTHOR (S) BIOSKETCHES}

Irajpoor A. A., Ph.D., Center of Excellence in Water Resources Engineering, University of Engineering and Technology, G. T. Road, Lahore, Pakistan. Email: a.irajpour@yahoo.com

Latif M., Ph.D., Centre of Excellence in Water Resources Engineering, University of Engineering and Technology, G. T. Road, Lahore, Pakistan. Email: drmlatif@yahoo.com 